Abstracta Iranica Abstracta Iranica

Revue bibliographique pour le domaine irano-aryen

Volume 31 | 2011

Comptes rendus des publications de 2008

\title{
Iranian Loanwords in Syriac. Wiesbaden, Reichert, 2008, xlvii-315 p. (Beiträge zur Iranistik 28)
}

\section{Florence Jullien}

\section{(2) OpenEdition}

1 Journals

Édition électronique

URL : http://journals.openedition.org/abstractairanica/39648

DOI : 10.4000/abstractairanica.39648

ISSN : 1961-960X

\section{Éditeur :}

CNRS (UMR 7528 Mondes iraniens et indiens), Éditions de l'IFRI

\section{Édition imprimée}

Date de publication : 15 mai 2011

ISSN : 0240-8910

\section{Référence électronique}

Florence Jullien, « Iranian Loanwords in Syriac. Wiesbaden, Reichert, 2008, xlvii-315 p. (Beiträge zur Iranistik 28) », Abstracta Iranica [En ligne], Volume 31 | 2011, document 205, mis en ligne le 11 octobre 2012, consulté le 27 septembre 2020. URL : http://journals.openedition.org/abstractairanica/39648 ; DOI : https://doi.org/10.4000/abstractairanica.39648

Ce document a été généré automatiquement le 27 septembre 2020.

Tous droits réservés 


\title{
Iranian Loanwords in Syriac. Wiesbaden, Reichert, 2008, xlvii-315 p. (Beiträge zur Iranistik 28)
}

\author{
Florence Jullien
}

L'A. examine les contacts linguistiques entre le moyen-perse et le syriaque, et plus généralement l'araméen, et s'intéresse particulièrement à la période sassanide, bien que son étude commence à la période achéménide. En première partie, l'A. nous livre une étude des conditions historiques et linguistiques ayant favorisé l'introduction d'un grand nombre de mots iraniens en syriaque, et évalue les conséquences de ces emprunts. La deuxième partie prend la forme d'un dictionnaire présentant une étymologie de chacun de ces termes iraniens, et fournissant exemples et références bibliographiques utiles. Ce travail remarquable permet de mieux saisir le phénomène de bilinguisme au sein de la société du monde iranien et les influences réciproques entre le moyen-perse et le syriaque. Soulignons le caractère de "conservatoire" que représente le syriaque pour nombre de termes jusqu'ici non attestés dans la documentation moyen-perse.

\section{INDEX}

Thèmes : 6.3. Autres religions 
AUTEURS

FLORENCE JULLIEN

EPHE - Paris 